\title{
THE EFFECT OF ECOTOURISM DEVELOPMENT ON MARINE CONSERVATION AREA IN WEST SUMATERA, INDONESIA
}

\author{
Lucky ZAMZAMI \\ Universitas Andalas, Departement of Anthropology, Padang, Indonesia, e-mail: luckyzamzami@ soc.unand.ac.id \\ Muhammad ALIMAN* \\ Universitas Negeri Malang, Departement of Geography, Malang, Indonesia, e-mail: alviageo@ gmail.com
}

\author{
AZWAR \\ Universitas Andalas, Departement of Sociology, Padang, Indonesia, e-mail: azwar.fisip@gmail.com
}

\begin{abstract}
Citation: Zamzami, L., Aliman, M., \& Azwar. (2021). THE EFFECT OF ECOTOURISM DEVELOPMENT ON MARINE CONSERVATION AREA IN WEST SUMATERA, INDONESIA. GeoJournal of Tourism and Geosites, 38(4), $1166-1174$. https://doi.org/10.30892/gtg.38423-757
\end{abstract}

\begin{abstract}
Ecotourism is critical in conservation areas for the development of mutual relationships between the community, government and tourist in the marine conservation area. However, the community must be key stakeholders in maximizing benefits to local communities and obtaining environmental support to effectively manage conservation areas. This study aimed 1) to determine the socio-economic impact on fishermen community for the marine resource conservation, b) to investigate the socio-economic impact on the community's understanding and respect to support conservation. This research was conducted in the Ampiang Parak and Maligi villages. The research used a structured questionnaire and qualitative method using observation and interview to evaluate the fishermen community involvement in ecotourism management. The research discussed and explained the source, income, and employment allocation of ecotourism regulations and economic participation for community programs. The management of the Ampiang Parak and Maligi conservation areas is still not aligned with the local community's ecotourism management, and the conservation area and tourist attraction has not yet been beneficial for the local community economy. The relationships betwe en ecotourism and sustainable growth, tourism, community, and natural resource conservation need to be improved.
\end{abstract}

Key words: Local Stakeholders; Ecotourism; Economic Participation; Marine Conservation Area; Nature Reserve

$* \quad * \quad * \quad * \quad * *$

\section{INTRODUCTION}

Ecotourism is facilitated by the harmonious natural-human connection. Conservation areas have long been viewed as places to visit because of natural and tourism resources services. In general, ecotourism in marine conservation areas gives benefits and has a socio-economic effect on the community (Cochrane, 2009). The tourism main attraction as conservation and development tools in marine conservation areas is to provide local economic advantages while maintaining ecological integrity through low-impact, non-consumptive usage of local resources (Arlym and Hermon, 2019). Thus, issues and problems related to people, conservation, and ecotourism, particularly in developing countries, have been raised while conservation is linked to promoting sustainable development through the conservation area and regional and community development strategies (Dalem, 2002; Nurhayati et al., 2019; Sumarmi et al., 2021). However, ecotourism is a complex activity that involves many stakeholders and occurs in vulnerable locations, both environmental and economic (Cochrane, 1996). In practice, the range of objectives listed is difficult to achieve (Nirwandar, 2015), and many types of environmental and ecological impacts are reported. Local communities are frequently excluded from tourism development (Kiper, 2013).

The separation between tourism theory and practice in marine conservation demonstrated the difficulty and uncertainty in managing the conservation areas and required an ecotourism assessment to determine the reasons for achieving the objectives. However, selecting appropriate evaluation parameters is essential as ecology and socio-economic systems are engaged in marine conservation areas (Sumarmi et al., 2021). Fishermen viewed ecotourism as a critical component of marine conservation areas to maximize biodiversity and socio-economic benefit while promoting the ecotourism industry and increasing conservation (Hitchner et al., 2009; Kiper, 2013; Nirwandar, 2015). However, conflicts between fishermen and marine conservation frequently develop during managing marine conservation areas (Kopnina, 2017). Thus, the local group has been described as the key factor for tourist assessments in marine conservation areas because it is connected with marine conservation and ecotourism management. Previous research based on job advantages (Stem et al., 2003; Zamzami et al., 2020) and income generated from tourism (Kiper, 2013; Manurung, 2000; Xu et al., 2009) and the local people perceptions are also used as the key factor in ecotourism assessments (Clifton and Benson, 2006; Mendes and Gunawan, 1994; Sproule and Suhandi, 1998). The marine conservation area has an important role in supporting sustainable fisheries management. The Indonesia Government has pledged 10 million hectares by the end of 2019 and 20 million hectares by

\footnotetext{
* Corresponding author
} 
2020 (Dermawan, 2010). By the end of 2009, the government completed 10 million hectares of conservation zones to maintain marine and fisheries reserves sustainably (Nirwandar, 2015). To date, the total marine conservation area has exceeded the 13.5 million hectares target. Indonesia's protected areas are largely remote and underdeveloped, with just 60 million people and a population density of over $60 \mathrm{~km}$ (Gurney et al., 2014). Thus, the rapid development of conservation areas and the immense human pressure have become obstacles in managing conservation areas in Indonesia. Ecotourism is the primary funding to maintain conservation areas and enhance the economic conditions of local residents because of the natural opportunities in conservation areas (Xu et al., 2009). Thus, studies of the local population's tourism status are limited, and the financial involvement in tourism and the factors influencing the tourism sector should be investigated to improve conservation environment management, particularly tourism development (Walpole and Goodwin, 2000).

Marine conservation is a geographic area that is recognized, dedicated, and managed legally to ensure long-term conservation, associated ecosystem services, and cultural values (Zamzami, 2019). It is known for avoiding coral reef stresses because of overfishing and also supporting community participation. Residency and predictable aggregation sites in Indo-Pacific have moved ocean turtle patterns, and coral reef studies in Australia showed that marine conservation areas are useful to protect these species (Waayers et al., 2012). Turtle cultivation has increased the number of turtles on the West Sumatra coast (Arlym and Hermon, 2019). While the marine conservation area is quite likely to affect local communities, it is generally only described scientifically. Marine conservation area assessments frequently overlook social implications, which might initially conflict with the community interest (Sumarmi et al., 2021). The marine conservation area mainly addresses the potential impacts on the fishing population. Earlier research has established that top-up management approaches are ineffective at accomplishing environmental goals (Zamzami et al., 2017). In many cases, a combination of top-up and bottom-up approaches is preferable rather than the strictly top-up approach. In combination with theoretical expectations, empirical findings enhanced support for upwards implemented municipal government conservation activities. Ecotourism is a part of sustainable development that focuses on human and natural ecosystems, accepted as a valuable instrument or economic growth and environmental activities in developed countries (Kiper, 2013).

Indonesia has developed principles and objectives in developing ecotourism in conservation areas. The principles include: (i) to maintain the balance in the ecosystem and life support system; (ii) to protect biodiversity and to use it as a genetic pool; (iii) to provide facilities for research, development, education, and training; (iv) to provide facilities for nature tourism and preserve local culture; and (v) to maintain the balance between economic interest and conservation of natural resources and their ecosystems (Manurung, 2000). In practice, ecotourism helped in involving the local community to preserve ecology and biodiversity for economic benefits. However, tourism development is a complicated process, often involving many stakeholders in economic and environmental places. Fishermen communities are frequently excluded from tourism development (Washington et al., 2018).In Indonesia, ecotourism offered some benefits for local communities, village development, educational experience, and marine conservation area, mainly focusing on ecology sustainability. It promoted appreciation of natural environmental and environmental education by exposing nature and marine conservation to visitors and locals. However, some conflicts always occurred between the fishermen community and the government. Thus, the local community was dissatisfied with the assessment of ecotourism, conservation, and other activities. Many studies have focused on income derived from ecotourism activities (Xu et al., 2009), employment opportunities in ecotourism (Stem et al., 2003), local fishers perception in marine conservation (Zamzami et al., 2020) and conflicts between local community and government (Markus, 2010; Ferrol-Schulte et al., 2015; White et al., 2005).

There were 50 national parks that existed from mountain, river, sea, and rain forests in Indonesia. It is included in the Indonesian government's commitment to ecotourism and sustainable tourism development with the national development plan for 2005-2025 and the tourism Act of Law No. 10 in 2009. Sustainability must consider the natural, social, economic, and cultural environment (Syamsu and Putrisari, 2016). Opportunities for tourism development in villages and rural coastal areas remained open. However, local communities in ecotourism are in high demand for infrastructural developments, especially transportation (Nugroho et al., 2016). Ecotourism contributes significantly to Indonesia's economy, and the supporting services are significant. Domestic tourists in 2018 have reached 300 million people with total revenue of 15.0 billion dollars, while international tourists have arrived at 11.00 million visits and have generated 13.3 billion dollars revenue (Nurhayati et al., 2019). Therefore, ecotourism is needed for rural coastal areas to take advantage of economic opportunities. This study aimed 1) to determine the socio-economic impact on fishermen community for the marine resource conservation (turtles, fish, and coral reefs), b) to investigate the socio-economic impact on the community's understanding and respect to support conservation. This study focused on fishermen joining the tourist industry voluntarily and the perceptions of problems and benefits for local people to engage in ecotourism. This article explored the conservation biodiversity, tourism creation, and marine conservation management. Ampiang Parak and Maligi were chosen as research locations due to difficulty and ambiguity in administering maritime conservation areas and possible conflicts between local economics, biodiversity protection, and sustainable growth. Therefore, the fishing community leaders were interviewed in two different areas that shared the same resource pool (turtles, fish, and coral reefs).

\section{METHODOLOGY}

\section{Research Location}

Indonesia is one of the archipelagic countries that has the longest coastline. West Sumatra Province has a coastline of 2,312.71 km with 185 islands (West Sumatra Regional Regulation, 2018), with the longest Pasaman Regency of $152 \mathrm{~km}$ and Pesisir Selatan Regency of $218 \mathrm{~km}$. The study was conducted through questionnaire survey and field interviews with the fishing communities: Ampiang Parak located in the southeast of Pesisir Selatan and Maligi village located in the 
northeast of Pasaman Barat. Ampiang Parak Village is located in Sutera District, Pesisir Selatan Regency. This village has 7 sub-village, namely Jorong Alai, Jorong Koto Tarok, Jorong Padang Laweh, Jorong Padang Tae, Jorong Pasar Amping Parak, Jorong Ujung Air and one jorong is still in the expansion stage. The population is 11,346 people, with 5526 women and 5820 men. The population occupancies are dominated by farmers, fishermen, government employees, traders, and laborers. Turtle Island and the surrounding area may be reached only with an outboard 40 PK boat, which takes 1.5 hours from Painan. Meanwhile, Painan District is approximately 1.5 hours away from Padang City.

The roads are in relatively good condition with spectacular panoramic views of the turtle island area, with ten varieties of algae discovered in the south of the island (Dermawan, 2010). Coral reef ecosystems around the turtle island are in good condition, such as branching, tables, encrusting, massive, submassive, digital, folio, mushroom, millipore, heliopora (Dermawan, 2010). The turtle conservation areas are shown in the following Figure 1.

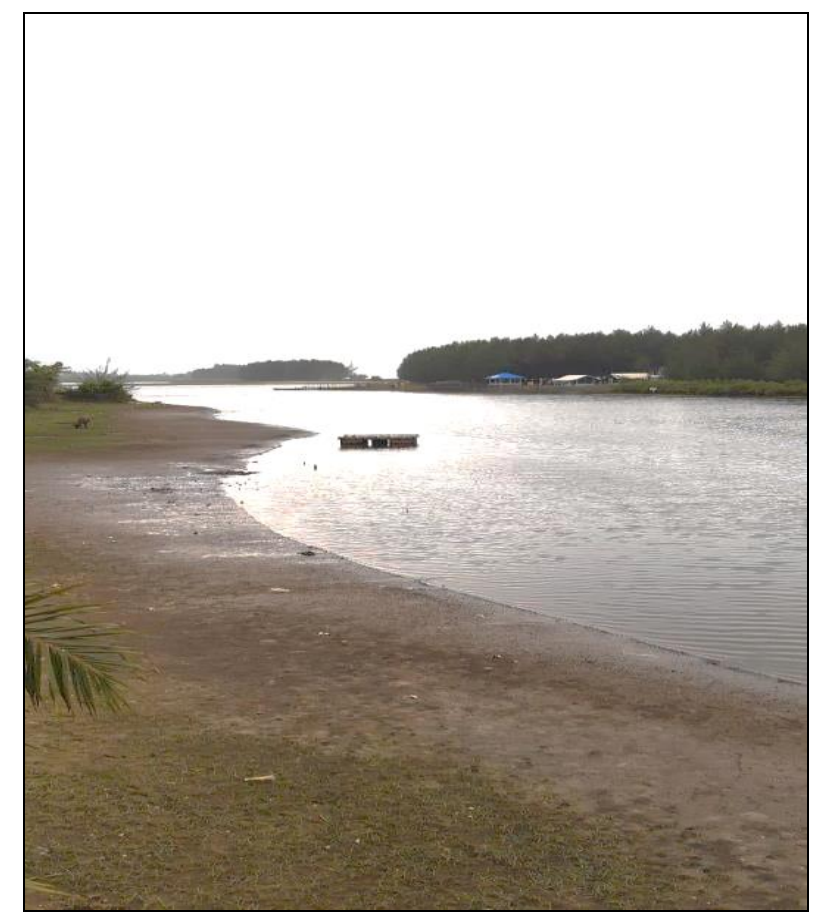

(a) Estuary Area of Ampiang Parak Village

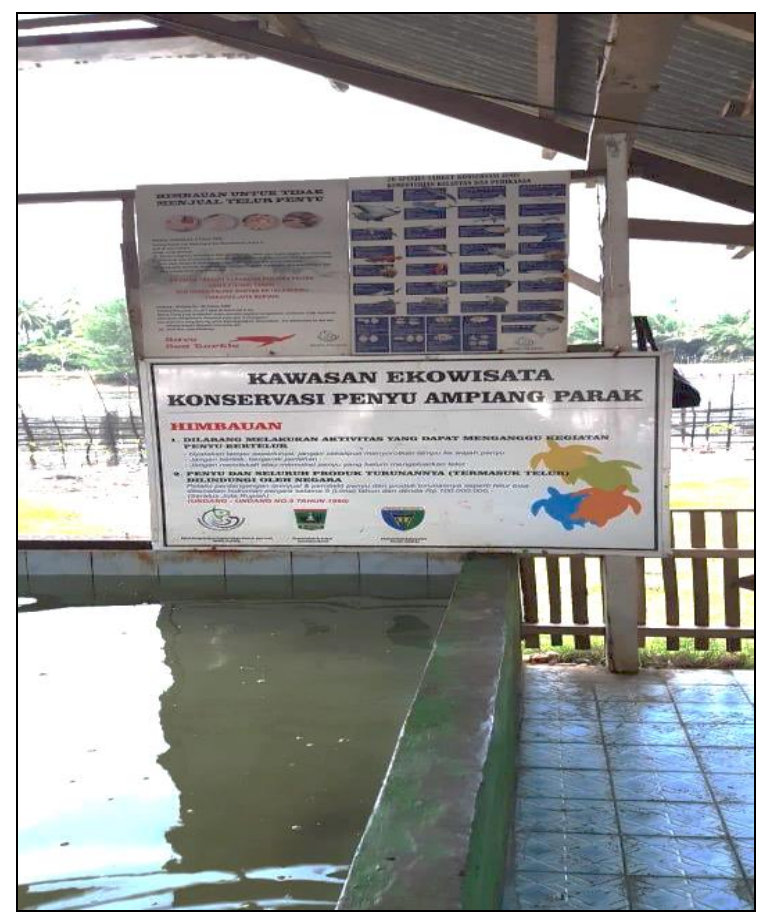

(b) Turtle conservation area in Ampiang Parak

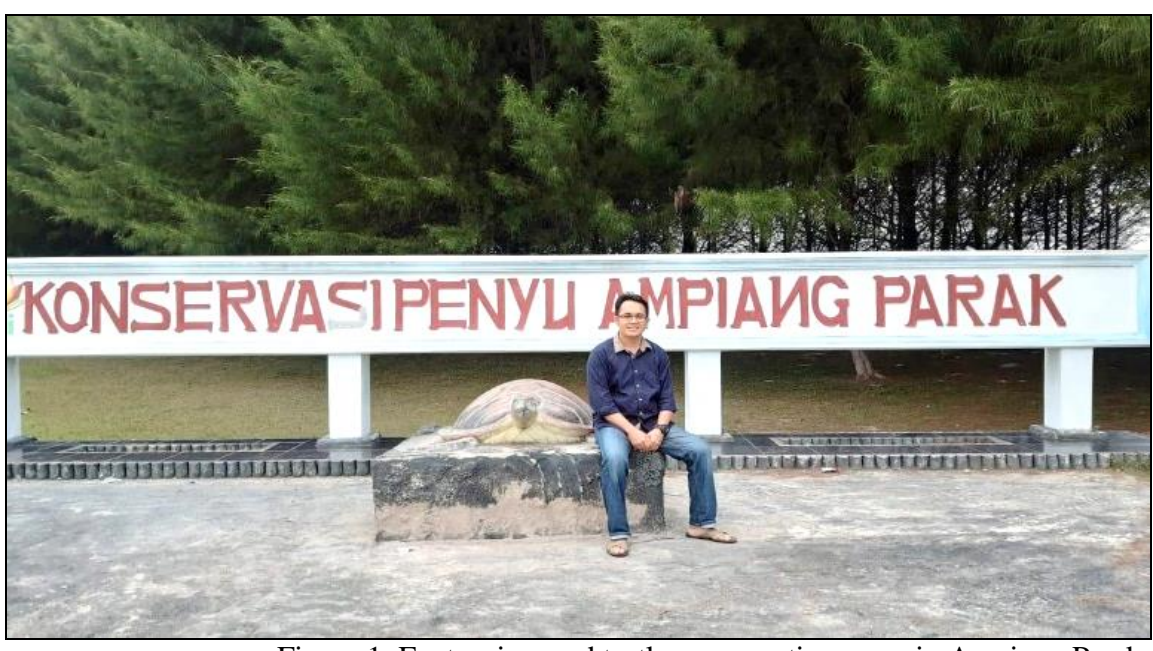

(c) Welcome statue in front of turtle conservation

Figure 1. Ecotourism and turtle conservation areas in Ampiang Parak

The development of the Brackish Water Protection Area in Maligi village, Sasak Ranah Pesisir District, Kabupaten West Pasaman, is authorized by West Pasaman Head Regent Decree No.188.45/326/BUP-PASBAR/2007 issued on June 7, 2007. The Maligi village included Jorong Pantai Indah, Jorong Suka Damai, Jorong Suka Jadi and Jorong Padang Jaya. Besides being a conservation area, this village has tourist attractions such as Bencah Galinggang Beach, Suak Lake, Sea Fir Forest, Indah Beach, Maligi Estuary, Berangin Beach, and Mangrove Forest. The village occupancies are dominated by fishermen, farmers, traders, and laborers. The facility was established at Maligi, District of Sasak Ranah, following the Brackish Water Protection Area, comprehensive germplasm management, and the balance and maintenance of regional ecosystems. The most popular types of coral reefs are found around the island's border. Great coral reefs were covered across the Teluk Air Bangis Island. Around 224.5 hectares of coral reef in West Pasaman can be conserved (Dermawan, 2010). The turtle conservation in Maligi village was shown in the following Figure 2. This study used quantitative and 
qualitative methods (Bryman, 2016; Neuman, 2006). The quantitative approach is a technique for identifying and describing the characteristics of variables in a situation (Mikkelsen, 2005). The qualitative approach describes variables through definitions, conceptual explanations, notes, or other recording field conditions (Babbie, 2010). The research analysis was selected with various criteria: 1) the research was related to an ecotourism development program, 2) the potential zone with limited natural damage as a growing attraction, 3) the basic range of tourism attractions includes turtle breeding, diving, and island beach trips. The research was conducted from December 2019 - February 2020.

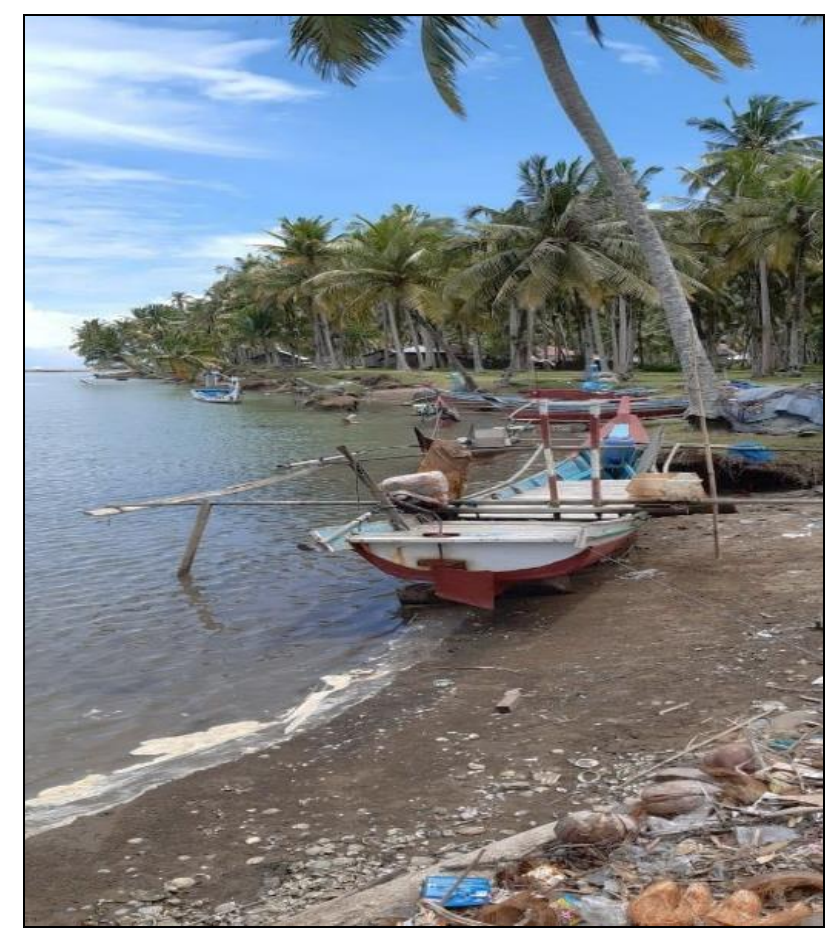

(a) Maligi Village fishing boat

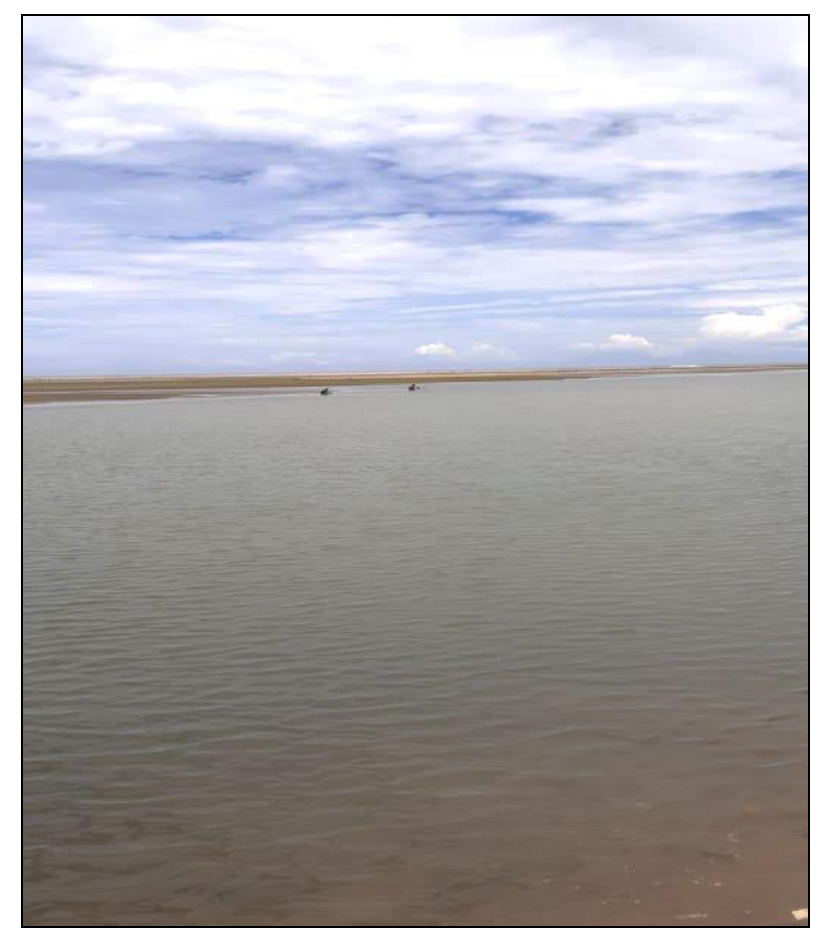

(b) Maligi Village beach area

Figure 2. The ecotourism area and turtle conservation in Maligi village

\section{Interviews}

The research consisted of 36 semi-structured interviews, 18 in Ampiang Parak and 18 in Maligi with 30 males and 6 females. The interviews were conducted with the fishermen community and local stakeholders. The research team used snowball sampling techniques to select the respondent. The researcher hired one local community member as a field guide. The interview guidelines included questions about the fishing community occupations, the socio-economic condition of information and knowledge provided to the environmental legislation application, and the conservation efforts. The fishing community occupation was shown in the following Table 1. The questions were asked in order to find out the respondent's expertise. The interview was coded after. The interview result has been documented and transcribed.

Table 1. The Fishing Community Occupation at Research Location

\begin{tabular}{|c|c|c|}
\hline $\begin{array}{c}\text { Research } \\
\text { Location }\end{array}$ & Occupations & $\begin{array}{c}\text { Number of } \\
\text { respondents }\end{array}$ \\
\hline Ampiang & Head of Village & 1 \\
\cline { 2 - 3 } Parak & Fishermen & 9 \\
\cline { 2 - 3 } & NGO representatives & 2 \\
\cline { 2 - 3 } & Ex-Fishermen/Wife & 3 \\
\cline { 2 - 3 } & Head of tourism office & 1 \\
\cline { 2 - 3 } & Head of marine office & 1 \\
\cline { 2 - 3 } & $\begin{array}{c}\text { Subsection Head of } \\
\text { Turtle Conservation }\end{array}$ & 1 \\
\hline Maligi & Head of Village & 1 \\
\cline { 2 - 3 } & Fishermen & 9 \\
\cline { 2 - 3 } & NGO representatives & 2 \\
\cline { 2 - 3 } & Ex-Fishermen/Wife & 3 \\
\cline { 2 - 3 } & Head of tourism office & 1 \\
\cline { 2 - 3 } & Head of marine office & 1 \\
\cline { 2 - 3 } & $\begin{array}{c}\text { Subsection Head of } \\
\text { Turtle Conservation }\end{array}$ & 1 \\
\hline & Total & 36 \\
\hline
\end{tabular}

Table 2. Response and Coding Categorisation

\begin{tabular}{|l|l|l|}
\hline \multicolumn{1}{|c|}{ Variable } & \multicolumn{1}{|c|}{ Description } & $\begin{array}{l}\text { Categorization } \\
\text { and Coding }\end{array}$ \\
\hline $\begin{array}{l}\text { (A) Consistency on } \\
\text { implementing } \\
\text { conservation rules }\end{array}$ & $\begin{array}{l}\text { The effect on marine conservation by referring } \\
\text { to respect regulations (fishing limitations, marine } \\
\text { conservation areas, protected species). }\end{array}$ & $\begin{array}{l}\text { Good =1 } \\
\text { Poor =2 } \\
\text { No answer =3 }\end{array}$ \\
\hline $\begin{array}{l}\text { (B) The economic } \\
\text { effect of conservation } \\
\text { initiatives to respon- } \\
\text { dents and societies }\end{array}$ & $\begin{array}{l}\text { The increase or decrease in respondent } \\
\text { economic income or society as a result of sea- } \\
\text { protection activities }\end{array}$ & $\begin{array}{l}\text { Increase =1 } \\
\text { Decrease =2 } \\
\text { No answer =3 }\end{array}$ \\
\hline $\begin{array}{l}\text { (C) The respondent's } \\
\text { experience on certain } \\
\text { lifestyle }\end{array}$ & $\begin{array}{l}\text { The individual or community access to } \\
\text { economic opportunities }\end{array}$ & $\begin{array}{l}\text { Easy access } \\
=1 \text { Poor/no } \\
\text { access =2 } \\
\text { No answer =3 }\end{array}$ \\
\hline $\begin{array}{l}\text { (D) Key } \\
\text { environmental } \\
\text { requirements }\end{array}$ & $\begin{array}{l}\text { The level of environmental awareness } \\
\text { (fishermen community, marine conservation and } \\
\text { ecotourism) to provide or consider authorities }\end{array}$ & $\begin{array}{l}\text { High =1 } \\
\text { Low =2 } \\
\text { No answer =3 }\end{array}$ \\
\hline $\begin{array}{l}\text { (E) Local } \\
\text { government } \\
\text { Connections }\end{array}$ & $\begin{array}{l}\text { The connections between local government with } \\
\text { conservation authorities, such as sea police and } \\
\text { other officials (dispute, cooperation, discussions, } \\
\text { interactions) }\end{array}$ & $\begin{array}{l}\text { Good =1 } \\
\text { Bad =2 } \\
\text { No answer =3 }\end{array}$ \\
\hline $\begin{array}{l}\text { Perception of local conservation programs and } \\
\text { motives }\end{array}$ & $\begin{array}{l}\text { Good =1 } \\
\text { Bad =2 } \\
\text { Notourism activities }\end{array}$ \\
\hline
\end{tabular}




\section{Analyze}

The interview data were analyzed into six categories: a) implementation of conservation rules, b) the conservation economic impact to the respondent and community, c) experience on a certain lifestyle, d) key environmental requirements, e) local government connections, f) were interpreted. The data collected were visualized into bar charts. The response categories were eliminated as there was no obvious null or response expectation during statistical checks. The covariance responses category matrix in six different classes was performed as part of the main analysis (CPA) to investigate the responses, shown in Table 3. The responses were categorized into: 1 (good), 2 (bad), 3 (no answer). Qualitative analysis was conducted to support quantitative data in statistics. The analysis was focused on socioeconomic conditions and local government collaborations in fisherman groups.

\section{RESULTS}

\section{Quantitative Analysis}

The responses are presented in categories related to the six factors. The findings indicated that the respondents valued the conversation activities but received low income. Most of the respondents have taken different jobs. Some respondents were aware of conservation regulations, but the involvement with environmental protection organizations was minimal. The respondent's responses were shown in the following Table 3.

Table 3. The Responses Result in Maximum Frequency Source: Research data analysis (2021)

\begin{tabular}{|c|c|c|c|c|}
\hline Variable & Response & Ampiang Parak $(n=18)$ & Maligi (n=18) & Total $(n=36)$ \\
\hline \multirow{3}{*}{$\begin{array}{l}\text { (A) Consistency on } \\
\text { implementing conservation rules }\end{array}$} & Good & $14(78 \%)$ & $10(55 \%)$ & $24(66 \%)$ \\
\hline & Poor & $4(22 \%)$ & $8(46 \%)$ & $12(34 \%)$ \\
\hline & No mention & 0 & 0 & 0 \\
\hline \multirow{3}{*}{$\begin{array}{l}\text { (B) The economic effect of } \\
\text { conservation initiatives to } \\
\text { respondents and societies }\end{array}$} & Increase & $18(100 \%)$ & $10(55 \%)$ & $28(77 \%)$ \\
\hline & Decrease & 0 & $8(46 \%)$ & $8(23 \%)$ \\
\hline & No mention & 0 & 0 & 0 \\
\hline \multirow{3}{*}{$\begin{array}{l}\text { (C) The respondent's experience } \\
\text { on certain lifestyle }\end{array}$} & Good & $16(88 \%)$ & $10(55 \%)$ & $26(72 \%)$ \\
\hline & Poor & $2(12 \%)$ & $8(46 \%)$ & $10(28 \%)$ \\
\hline & No mention & 0 & 0 & 0 \\
\hline \multirow{3}{*}{$\begin{array}{l}\text { (D) Key environmental } \\
\text { requirements }\end{array}$} & High & $15(83 \%)$ & $10(55 \%)$ & $25(69 \%)$ \\
\hline & Low & $3(17 \%)$ & $8(46 \%)$ & $11(31 \%)$ \\
\hline & No mention & 0 & 0 & 0 \\
\hline \multirow{3}{*}{$\begin{array}{l}\text { (E) Local government } \\
\text { Connections }\end{array}$} & Good & $18(100 \%)$ & $10(55 \%)$ & $28(77 \%)$ \\
\hline & Bad & 0 & $8(46 \%)$ & $8(23 \%)$ \\
\hline & No mention & 0 & 0 & 0 \\
\hline \multirow{3}{*}{$\begin{array}{l}\text { (F) Perceptions on ecotourism } \\
\text { activities }\end{array}$} & Good & $18(100 \%)$ & $10(55 \%)$ & $28(77 \%)$ \\
\hline & Bad & 0 & $8(46 \%)$ & $8(23 \%)$ \\
\hline & No mention & 0 & 0 & 0 \\
\hline
\end{tabular}

The variables of $\mathrm{A}, \mathrm{B}, \mathrm{C}, \mathrm{D}$, and $\mathrm{F}$ have relatively high positive CP1 loads, showing that high values (good) for this CP are correlated. The respondent mentioned that they often had a better engagement with marine conservation. The variables of $\mathrm{A}, \mathrm{F}$ had relatively high CP2 loads, while $\mathrm{C}$ had a high negative CP load. The respondents with different jobs have low positive views for marine conservation. CP2 contributes to only $10 \%$ of the variance, and hence the trend observed in CP1 should emphasize a significant relationship between these three variables: C, A, and F. The variable's load analysis was shown in the following Figure 3.

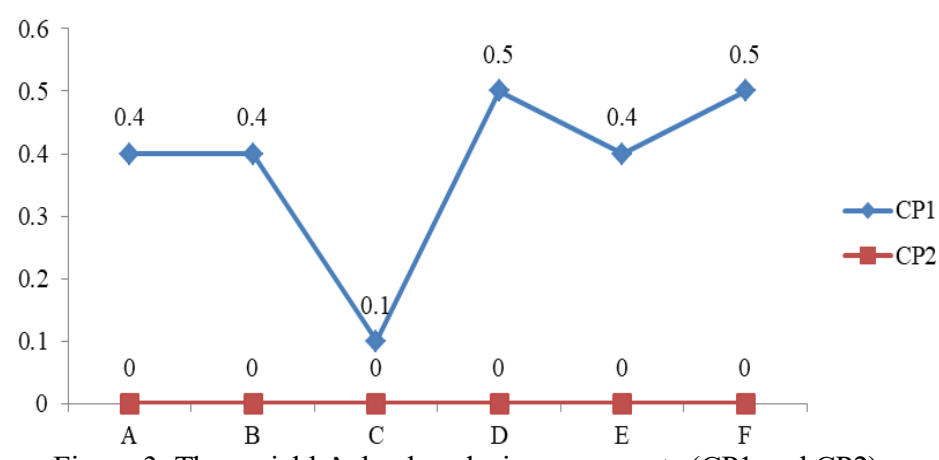

Qualitative Analysis: The economic effect of conservation initiatives to respondents and societies (B) and experience on certain lifestyle $(\mathbf{C})$

In general, $77 \%$ of respondents improved their financial situation since marine conservation activities began, whereas $23 \%$ experienced negative impacts. $46 \%$ of respondents reported having opportunities for lifestyle options, while $23 \%$ reported having complicated options. However, the situation varies between the locations. In the Ampiang Parak conservation area, most respondents negatively impacted the economic situation because of limited access to fishing areas due to the zoning system. As the fishing zones moved farther, the cost of fuel for fishing boats increased. Additionally, fishing gear was restricted, catch capacity was decreased, and existing equipment was made useless, requiring new expenses. 55\% of residents in Maligi village have a simple family lifestyle but lack the economic resources to launch a small shop. Conservation organizations provided visitors and guides with alternative vocations, such as kayaking, but it is still limited. Being a tourist guide on the island required years of preparation, training, and studying flora and fauna, making it a highly specialized profession (Zamzami et al., 2021). 
$46 \%$ of respondents in the Maligi conservation area reported an increased income, while none reported any negative impacts. Some part-time tourists identified that the income depends on the conservation area. The most easily perceived economic opportunities used as an income source for most respondents are hospitality, such as transporting visitors to famous scuba diving spots or visiting some environmental sites. The village economy depended on fishing. $80 \%$ of occupancies were related to fisheries (20\% of them are small-scale fishermen). Thus, $46 \%$ of respondents experienced a negative impact of conservation benefits. As fishing has been leased, the expenses fluctuate significantly according to commodity prices. The quantity of fish delivered to the marketplace affected the economy, reducing work hours in fishing (some are related to mini restaurants or tuna factories). Many of the fishers studied had economic opportunities, but some focused on small businesses or little restaurants, focusing entirely on the fish market.

\section{Qualitative Analysis: Key environmental requirements (D)}

$69 \%$ of respondents showed a high level of local environmental skills, and $31 \%$ showed a low level. However, it is different between locations. $83 \%$ of respondents in the Ampiang Parak conservation area showed a significant level of management skills, and 17\% were low. Many of the residents were unsure of places to fishing, gears needed, or fishing regulations. At times, fishing areas have been modified without first informing the fishermen community, resulting in community members' dissatisfaction. Meanwhile, the majority of respondents in Ampiang Parak reported having more information to control marine conservation areas. It may be because the non-governmental organization (NGO) has been informing and updating stakeholders continually since the beginning. Some respondents in the Ampiang Parak conservation area would have a good understanding of policies to support local fishing businesses. Respondents stated that government officials have visited on multiple occasions to discuss restrictive fishing regulations.

\section{Qualitative Analysis: Local government connections (E), perceptions on ecotourism activities (F)}

$77 \%$ of respondents mentioned a great relationship with the protection officers, and $23 \%$ said negative. $55 \%$ stated to have moderate opinions, while $46 \%$ expressed negative views about the government's efforts to protect the environment. In Ampiang Parak, relationships between fishermen and conservation authorities (local government) were often tense. Although no negative relationships have been documented, $100 \%$ of respondents report having positive interactions with conservation authorities. Respondents stated that tour guides often used aggressive or offensive strategies in the conservation area. A dialog was created between stakeholders, but it was lacking as the community member's perceptions were not properly considered while constructing the protection system. However, the ecotourism management respondent expressed gratitude for guarding the sea against foreigners using harmful fishing equipment such as bombs.

The concept and impact of ecotourism management in the Maligi fishing community were relatively low. Only 55\% of the participants shared positive opinions, while $46 \%$ had negative opinions. Perceiving unfairness in the protection system was a common issue. The respondents felt that the restrictions on fishery activities were so strict that they needed to show identification cards constantly. Most of the respondents viewed the security of the coasts and marine activities as fair and described management's behavior as friendly and supportive, placing a high value on behavior. Fishermen received training from marine conservation management to improve ecotourism management. Fishing activities had improved because of avoiding destructive fishing gear such as bombers or poison. The connection between fishermen and the marine conservation authorities seems to be influenced by frequent communication. Otherwise, some respondents expressed dissatisfaction with the Padang administration's failure to secure the village. Most residents in Maligi indicated a lack of trust in the conservation authorities. It could be related to the negative effects perceived from protecting the local economy and limiting job opportunities. Only $23 \%$ of the respondents reported good relations with the authorities. Although the government has developed strategies to minimize income loss, disbelief occurred in the government commitments. However, $30 \%-40 \%$ of respondents expressed positive opinions about conservation programs in protecting turtle and coral reefs species. While fishermen have supported conservation programs in certain ways, the economic consequences have resulted in bad cooperation and negative public perception (Zamzami et al., 2021).

\section{Qualitative Analysis: Consistency of conservation enforcement rules (A)}

$66 \%$ of respondents had high support for conservation activities, while $34 \%$ was low. However, it is contrasted between 2 locations. Most respondents in Ampiang Parak reported having good collaboration, but it was low in Maligi. The respondents in Maligi village took a negative attitude towards marine conservation authorities and ignored the regulations. It is related to dissatisfaction with a lack of awareness about the laws. In the past, a fisherman was arrested by maritime police for using unlicensed facilities and carried to Pasaman Barat district. Therefore, relations between Maligi's marine police and fishermen's communities appear to have been particularly tense, impacting the support with conservation legal.

The significant connection in Ampiang Parak had made some impacts on the respondents, such as economic improvement, access to job opportunities, good relations with government, and positive perception about conservation. The respondent also received important information in supporting conservation. Furthermore, local residents would instead approach marine conservation groups to develop conservation areas rather than following the government's decision. Some parties continuously hold an open discussion to create and execute the marine conservation area. It might have influenced local residents' positive views of conservation programs and developed positive relationships with governments.

Meanwhile, most of the respondents in Maligi perceived local regulations as loose, making this location less consistent. It could affect the value and interaction of turtles and fish in the fishery industries. Fishermen recognized that conservation areas had caused a drop-in sale while not giving enough income for the family. It showed challenges in the legal protection 
of turtles and fish, and the economic effect resulted for fishermen. Frequent conversations with government officials have informed the local fishing community that population drops have impacted tortoises and fish species. It resulted in a decrease in the fish accessible on the traditional market, which increased demand even more. Despite limited knowledge of protection and punishment, economic benefit has increased for fishermen to harvest certain fish species. The qualitative analysis has categorized the interview result based on each research locations. The result is shown in the following Table 4.

Table 4. The conservation activities in research location (Source: Research data analysis 2021)

\begin{tabular}{|l|l|l|l|}
\hline Research Location & \multicolumn{1}{|c|}{ Conservation Type } & \multicolumn{1}{c|}{ Enforcement Type } & Fishing Community Implications \\
\hline Ampiang Parak & Turtle, fish fin, coral reefs & $\begin{array}{l}\text { Local government, members } \\
\text { of NGOs, group of fishermen }\end{array}$ & $\begin{array}{l}\text { Limits on fishing gear; limits on } \\
\text { fishing areas }\end{array}$ \\
\hline Maligi & $\begin{array}{l}\text { Coral reefs, mangroves, seagrass, sea turtles } \\
\text { (leatherback turtle (Dermochelys coriacea) habitat. }\end{array}$ & $\begin{array}{l}\text { Local government, members } \\
\text { of NGOs, group of fishermen }\end{array}$ & $\begin{array}{l}\text { Limits on fishing gear; limits on } \\
\text { fishing areas }\end{array}$ \\
\hline
\end{tabular}

\section{DISCUSSIONS}

Fishermen communities are most concerned about the economic benefits of ecotourism development (Arlym and Hermon, 2019; Clifton and Benson, 2006). While marine conservation areas are closely tied to the fishing community and biodiversity protection, economic benefits contribute significantly to ecotourism. The fishing community benefited from maintaining biodiversity and natural resources. Increased economic citizens' participation in economics was also considered a critical aspect of ecotourism (Dalem, 2002). The economic connection between locals and biodiversity is limited, and the local tourist's participation is low. The community was important to conserving ecotourism and needed an income urgently ( $\mathrm{Xu}$ et al., 2009). However, the local fishermen's income on ecotourism management is less profitable due to less strategic service areas. Only a few residents with expertise, commercial assets, and a special position gained profit from the tourism. Moreover, the local government kept revenues collected from admission fees to develop tourism resources but not distributed to the fishermen community.

Resident participation provided an opportunity to support conservation, but a lack of economic opportunities was likely to reduce the earnings. Also, tourism development involves the exploration and evolution of natural resources. The study found that almost all fishermen, particularly women, provide small businesses to visitors, and $26 \%$ of women produce dry fish and sell them to tourists for family income. Although regional wildlife conservation is beyond the scope of this paper, the relationship grows if no other alternatives are found (Zamzami et al., 2019). Tourist areas used for environmental development are also viewed as a timebomb for biodiversity protection.

Besides ensuring efficient allocation of tourism benefits, local economic participation aimed to increase urban growth's economic potential by limiting import loss (Eriksson et al., 2019). The loss of household income depended on imports from the global fish supply and other companies. The findings indicated that ecotourism income was not distributed fairly among locals and that the differences are related to location, competence, and resource availability. Moreover, local management should set fair profit distribution arrangements. Maligi village is located in a marine conservation area with limited access to processed resources. Having a large number of employees causes the relationship between ecotourism and economic growth to become unbalanced. Therefore, it is important to use local products and employ fishermen to reduce economic loss. There are various tourism opportunities that have not yet been used in the West Pasaman district, such as Sasak culture and other natural views. Despite good infrastructure and reputation, few tourists spend more time in the research area (Heng et al., 2016).

Furthermore, tourism facilities should be built to maintain the ecosystem, and measures should be implemented to improve visitor numbers and duration of stay in the research area. A system is needed to balance the community's revenue through secondary and tertiary expenses. Opportunities for local residents to assist in conservation area management might be an important encouragement. The unemployment rate has increased at a higher rate than the overall population in the research location. A lack of jobs and little farmland contributed to excess work availability, which is essential for conserving and protecting natural ecosystems. The issue of poor family life and an excessive workforce in tourism development must be discussed. Although tourism in conservation areas is designed for local residents, entry into the business is not always straightforward, especially in isolated areas. Difficulties in hiring local residents are caused by: existing skills, ability to learn and develop new skills, ability to compete with non-locals, and ability to maintain conservation areas. Some young workers do not get employment benefits and only do simple jobs. The main element that causes an imbalance between fishermen and tourists is limited working capital and lack of skills (Sumarmi et al., 2021). It led to delays in village development and low benefits from ecotourism.

Based on the findings, we offer a strategy for sustainable ecotourism management in Ampiang Parak and Marigi villages, namely the Bottom-Up strategy. This strategy fits with the egalitarian culture in West Sumatra. The local wisdom of West Sumatra recognizes the cooperation system in making decisions, including in ecotourism management. Management with a bottom-up strategy can accommodate all the stakeholder objectives. The Pentahelix element involved in ecotourism management is local governments, fishing communities, academics, tourism managers/investors, and journalists (Yuningsih et al., 2019). Therefore, a workshope is needed to develop partnership, collaborarion and trust among ecotourism management and parties (Waayers et al., 2012). The involvement of local communities is limited to small shop services and mini restaurants. There is not much diversity of occupancies. It is necessary to conduct a group discussion forum for all stakeholder components to increase community involvement regarding the opportunities offered to tourists. The involvement includes: providing fishing tours, adding lodging, providing unique souvenirs, serving dives to 
coral reefs, and providing public facilities such as public bathrooms and parking areas (Sumarmi et al., 2020). Therefore, it is expected to form an integrated management organization in this ecotourism area. Competitive fair play should be given to both local and non-local participants. However, residents should be given priority in tourism activities to avoid discrimination. Therefore, ecotourism management is required to give training and resources to involve fishermen in the industry to increase their employment skills in ecotourism management. Simple businesses and technology using social skills are more effective. Furthermore, the conservation area would have difficulty accommodating and sustaining all of the required work due to the fragile environment and the expanding number of local workers. However, proper training may be necessary for young workers to survive outside the Ampiang Parak and Maligi conservation areas.

\section{CONCLUSION}

Following this study's findings, fishermen's communities place a high priority on their economic conditions when confronted with marine conservation activities that could have an impact on their livelihoods. This provides weight to the notion that local communities should place a high priority on social justice and equity when developing conservation plans. More specifically, it is suggested by the findings that prioritizing stakeholder participation, ongoing conversation, and transparency in decision-making may improve trust and promote the equitable distribution of conservation benefits, ultimately leading to better conservation outcomes.

Conservation authorities may benefit from this finding because underprivileged stakeholders were more likely to breach conservation regulations. Also, when implementing marine conservation, integrating planning for alternative livelihoods that are compatible with the local context can aid in improving long-term compliance with conservation standards by local residents. Stakeholder participation is critical for long-term economic, social, and environmental sustainability, as demonstrated by the findings of the study in its overall conclusion. The goal of marine conservation area and tourism is to create a win-win situation for locals, the marine conservation area, and tourism. However, complicated natural, social, and economic backdrops make such ideal partnerships difficult to achieve.

The findings of the current paper, which are characteristic of tourism development in marine conservation areas, particularly in the developing world, may have far-reaching consequences for marine conservation area management and tourism development, particularly in the developing world. Based on the conclusions of this study, a number of policy instruments can be recommended. First and foremost, local capability must be built up through education and vocational training programs. Second, eco-friendly tourism products can be customized to reflect the unique natural and cultural aspects of the location where they are offered. It is also necessary to implement financial support and economic compensation methods for poor local stakeholders, as previously stated. Finally, tax leverage may be beneficial in ensuring that development earnings and conservation costs are distributed in a more equitable manner. They would be more prepared to serve as coordinators in the areas of tourism development and general marine conservation area management, and they should assist in the creation of positive working relationships among the many actors and stakeholders.

\section{Acknowledgments}

This research was supported by grants No. T/3/UN.16.17/PP, Soshum-KRP2GB/LPPM/2020 from the Universitas Andalas.

\section{REFERENCES}

Arlym, L., \& Hermon, D. (2019). Strategy of ecotourism development in Pariaman city. IOP Conference Series: Earth and Environmental Science, 314, 12039. https://doi.org/10.1088/1755-1315/314/1/012039

Babbie, E. (2010). The Practice of Social Research. Earl R. Babbie. https://www.worldcat.org/title/practice-of-social-research/oclc/662584565

Bryman, A. (2016). Social Research Methods. Oxford University Press. https://ktpu.kpi.ua/wp-content/uploads/2014/02/social-researchmethods-alan-bryman.pdf

Clifton, J., \& Benson, A. (2006). Planning for Sustainable Ecotourism: The Case for Research Ecotourism in Developing Country Destinations. Journal of Sustainable Tourism, 14(3), 238-254. https://doi.org/10.1080/09669580608669057

Cochrane, J. (1996). The Sustainability of ecotourism in Indonesia: fact and fiction. Environmental Change in South-East Asia: People, Politics and Sustainable Development. 237-259. https://www.taylorfrancis.com/chapters/oa-edit/10.4324/978020398300323/sustainability-ecotourism-indonesia

Cochrane, J. (2009). New directions in Indonesian ecotourism. Tourism in Southeast Asia: Challenges and New Directions, $254-269$.

Dalem, A. (2002). Ecotourism in Indonesia. Linking Green Productivity to Ecotourism: Experiences in the Asia-Pacific Region. Tokyo: Asian Productivity Organisation. https://www.apo-tokyo.org/publications/wp-content/uploads/sites/5/ind_gp_lgep.pdf

Dermawan, A. (2010). 42 Indonesian marine conservation areas. Directorate of Aquatic and Marine Resources Conservation Directorate General of Marine, Coasts and Small Islands Ministry of Marine Affairs and Fisheries Republic of Indonesia.

Eriksson, B., Johansson, F., \& Blicharska, M. (2019). Socio-economic impacts of marine conservation efforts in three indonesian fishing communities. Marine Policy, 103, 59-67. https://doi.org/10.1016/j.marpol.2019.02.007

Ferrol-Schulte, D., Gorris, P., Baitoningsih, W., Adhuri, D.S., \& Ferse, S.C.A. (2015). Coastal livelihood vulnerability to marine resource degradation: a review of the Indonesian national coastal and marine policy framework. Marine Policy, 52, $163-171$. https://doi.org/10.1016/j.marpol.2014.09.026

Gurney, G.G., Cinner, J., Ban, N.C., Pressey, R.L., Pollnac, R., Campbell, S.J., \& Setiawan, F. (2014). Poverty and protected areas: an evaluation of a marine integrated conservation and development project in Indonesia. Global Environmental Change, 26, 98-107. http://doi.org/10.1016/j.gloenvcha.2014.04.003

Heng, X.P., Wang, Z.F., Dai, Q.Q., \& Jiang, Q.Z. (2016). The roles of local knowledge in identifying water security pattern: a case study of Longxing and Shichuan township in yulin watershed, Chongqing. Shengtai Xuebao/ Acta Ecologica Sinica, 36(13), 4152-4162. https://doi.org/10.5846/stxb201410202059 
Hitchner, S.L., Apu, F.L., Tarawe, L., Aran, S.G.S.N., \& Yesaya, E. (2009). Community-based transboundary ecotourism in the heart of Borneo: A case study of the Kelabit Highlands of Malaysia and the Kerayan Highlands of Indonesia. Journal of Ecotourism, 8(2), 193-213. https://doi.org/10.1080/14724040802696064

Kiper, T. (2013). Role of ecotourism in sustainable development. InTech. https://doi.org/10.5772/55749

Kopnina, H. (2017). Just conservation: in defense of environmentalism. Handbook of Engaged Sustainability: Contemporary Trends and Future Prospects. Ed. by S. K. Dhiman and J. Marques, 201 - 220. Ham: Springer International Publishing. https://doi.org/10.1007/978-3-319-53121-2_5-1

Manurung, R. (2000). Ecotourism in Indonesia. In Linking Green Productivity to Ecotourism: Experiences in the Asia-Pacific Region, Report of the APO Workshop on Green Productivity and Eco-Tourism held in Bali, Indonesia, 98-103.

Markus, T. (2010). Towards sustainable fisheries subsidies: Entering a New Round of Reform under the Common Fisheries Policy. Marine Policy, 34(6), 1117-1124. https://doi.org/10.1016/j.marpol.2010.03.011

Mendes, J.P., \& Gunawan, M.P. (1994). Emergence of ecotourism in Indonesia: A national park case study. Journal of Regional and City Planning, 5(16a), 33-44. https://journals.itb.ac.id/index.php/jpwk/article/view/5746

Mikkelsen, B. (2005). Methods for development work and research: a new guide for practitioners. SAGE Publications India Pvt Ltd. http://dx.doi.org/10.4135/9788132108566

Neuman, W.L. (2011). Social research methods: Qualitative and Quantitative Approaches. social research. $7^{\text {th }}$ edition. Univerity of Wisconsin, Whitewater.

Nirwandar, S. (2015). Ecotourism in Indonesia. Jakarta: Ministry of Tourism and Creative Economy.

Nugroho, I., Pramukanto, F.H., Negara, P.D., Purnomowati, W., \& Wulandari, W. (2016). Promoting the rural development through the ecotourism activities in Indonesia. American Journal of Tourism Management, 5(1), 9-18. https://doi.org/10.5923/j.tourism.20160501.02

Nurhayati, A., Aisah, I., \& Supriatna, A.K. (2019). Model Development of a synergistic sustainable marine ecotourism-a case study in Pangandaran region, west java province, Indonesia. Sustainability, 11(12), 3418. https://doi.org/10.3390/su11123418

Sproule, K.W., \& Suhandi, A.S. (1998). Guidelines for community-based ecotourism programs. Lessons from Indonesia. Ecotourism: A Guide for Planners and Managers. 215-235.http://d2ouvy59p0dg6k.cloudfront.net/downloads/guidelinesen.pdf

Stem, C.J., Lassoie, J.P., Lee, D.R., \& Deshler, D.J. (2003). How'eco'is ecotourism? A comparative case study of ecotourism in Costa Rica. Journal of Sustainable Tourism, 11(4), 322-347. https://doi.org/10.1080/09669580308667210

Sumarmi, Kurniawati, E., \& Aliman, M. (2020). Community Based Tourism (Cbt) to establish blue economy and improve public welfare for fishing tourism development in klatak beach, tulungagung, Indonesia. GeoJournal of Tourism and Geosites, 31(3), 979-986. https://doi.org/10.30892/gtg.31307-530

Sumarmi, S., Arinta, D., Suprianto, A., \& Aliman, M. (2021). The development of ecotourism with community-based tourism (CBT) in clungup mangrove conservation (CMC) of tiga warna beach for sustainable conservation. Folia Geographica, 63(1), $123-142$. http://www.foliageographica.sk/unipo/journals/2021-63-1/580

Syamsu, M.N., \& Putrisari, M.B. (2016). Community based ecotourism development of sebangau national Park in Central Kalimantan Indonesia. International Journal of Tourism and Hospitality Study, l(1).

Waayers, D., Lee, D., \& Newsome, D. (2012). Exploring the nature of stakeholder collaboration: A case study of marine turtle tourism in the Ningaloo region, Western Australia. Current Issues in Tourism, 15(7), 673-692. https://doi.org/10.1080/13683500.2011.631697

Walpole, M.J., \& Goodwin, H.J. (2000). Local economic impacts of dragon tourism in Indonesia. Annals of Tourism Research, 27(3), 559-576. http://doi.org/10.1016/s0160-7383(99)00088-2

Washington, H., Chapron, G., Kopnina, H., Curry, P., Gray, J., \& Piccolo, J.J. (2018). Foregrounding ecojustice in conservation. Biological Conservation, 228, 367-374. http://doi.org/10.1016/j.biocon.2018.09.011

White, A.T., Christie, P., D’Agnes, H., Lowry, K., \& Milne, N. (2005). Designing ICM projects for sustainability: lessons from the Philippines and Indonesia. Ocean \& Coastal Management, 48(3-6), 271-296. http://doi.org/10.1016/j.ocecoaman.2005.04.007

Xu, J., Lü, Y., Chen, L., \& Liu, Y. (2009). Contribution of tourism development to protected area management: local stakeholder perspectives. International Journal of Sustainable Development \& World Ecology, 16(1), 30-36. https://doi.org/10.1080/13504500902757189

Yuningsih, T., Darmi, T., \& Sulandari, S. (2019). Model Pentahelik dalam Pengembangan Pariwisata di Kota Semarang. Journal of Public Sector Innovations. 3 (2), 84-93. http://dx.doi.org/10.26740/jpsi.v3n2.p84-93

Zamzami, L., Effendi, N., Syahrizal., \& Ermayanti. (2017). The local wisdom in marine resource conservation in indonesia: a case study of newcomers in pariaman west sumatra. In Proceedings of the 2nd International Conference on Social and Political Development (ICOSOP 2017) (pp. 391-400). The Atlantis Press. https://doi.org/10.2991/icosop-17.2018.61

Zamzami, L. (2019). The local wisdom in marine resource conservation for strategies of poverty reduction in Indonesia. https://doi.org/10.5281/ZENODO.3534104

Zamzami, L., Ermayanti, E., Hendrawati, H., \& Miko, A. (2020). Socio-Cultural impacts of marine conservation areas in Indonesian fishing communities. IOP Conference Series: Earth and Environmental Science, 430, 12016. https://doi.org/10.1088/1755-1315/430/1/012016

Zamzami, L., Iwabuchi, A., Effendi, N., Ermayanti, Hendrawati, \& Miko, A. (2019). The development of marine resource conservation in Indonesia. Journal of Advanced Research in Dynamical and Control Systems, 11(8 Special Issue), $1281-1288$. http://repo.unand.ac.id/32194/1/Article_Jurnal JARDCS Special Issues_Lucky Zamzami.pdf

Zamzami, L., Azwar, Ermayanti, \& Hendrawati. (2021). Development of Marine Ecotourism in Indonesia: Case of Maligi Nature Reserve, Province of West Sumatra. IOP Conference Series: Earth and Environmental Science, 695(1), 012029. https://doi.org/10.1088/1755-1315/695/1/012029

\footnotetext{
Article history: Received: 26.05.2021 Revised: 23.09.2021 Accepted: 28.10.2021 Available online: 15.11 .2021
} 